\title{
The Emerging Role of G $\beta$ Subunits in Human Genetic Diseases
}

\author{
Natascia Malerba ${ }^{1,+}(\mathbb{D})$, Pasquelena De Nittis ${ }^{2,+} \mathbb{D}$ and Giuseppe Merla ${ }^{1, *(\mathbb{D})}$ \\ 1 Division of Medical Genetics Unit, IRCCS Casa Sollievo della Sofferenza, Viale Cappuccini, \\ 71013 San Giovanni Rotondo (FG), Italy; n.malerba@operapadrepio.it \\ 2 Center for Integrative Genomics, University of Lausanne, CH-1015 Lausanne, Switzerland; \\ pasquelena.denittis@unil.ch \\ * Correspondence: g.merla@operapadrepio.it; Tel.: +39-0882-416350 \\ + These authors contributed equally to this work.
}

Received: 23 October 2019; Accepted: 29 November 2019; Published: 4 December 2019

\begin{abstract}
Environmental stimuli are perceived and transduced inside the cell through the activation of signaling pathways. One common type of cell signaling transduction network is initiated by G-proteins. G-proteins are activated by G-protein-coupled receptors (GPCRs) and transmit signals from hormones, neurotransmitters, and other signaling factors, thus controlling a number of biological processes that include synaptic transmission, visual photoreception, hormone and growth factors release, regulation of cell contraction and migration, as well as cell growth and differentiation. G-proteins mainly act as heterotrimeric complexes, composed of alpha, beta, and gamma subunits. In the last few years, whole exome sequencing and biochemical studies have shown causality of disease-causing variants in genes encoding G-proteins and human genetic diseases. This review focuses on the G-protein $\beta$ subunits and their emerging role in the etiology of genetically inherited rare diseases in humans.
\end{abstract}

Keywords: heterotrimeric G-proteins; $\beta$ subunits; neurodevelopmental disorders; human genetic diseases

\section{G-Protein-Coupled Receptors (GPCRs) and Heterotrimeric G-Proteins}

The G-Protein-Coupled Receptor (GPCR) superfamily includes over 800 members in humans [1] and is the largest group of cell-surface seven-transmembrane receptors [2]. They translate the signal from extracellular ligands into intracellular responses [3]. The GPCRs have a ligand-binding pocket, with seven motif $\alpha$-helices, in the extracellular region, and a cytoplasmic domain engaged in G-proteins binding, guanosine triphosphate (GTP)-binding heterotrimers, consisting of $\alpha, \beta$, and $\gamma$ subunits $[4,5]$.

When inactive, the G-protein $\alpha$ subunit is linked to guanosine diphosphate (GDP). Ligand-activated GPCRs catalyze the exchange of GDP with GTP on G $\alpha$, promoting its dissociation from G $\beta \gamma$ (Figure 1). The G $\alpha \beta \gamma$ dissociation, in turn, promotes the activation of the G $\alpha$ and $G \beta \gamma$ units that activate downstream factors, thus regulating an array of cellular functions such as cell contraction, excitability, migration, cell growth, and differentiation [6,7]. Notably, the combinatorial association of the distinct G-protein subunit subtypes, comprising at least $20 \mathrm{G} \alpha, 5 \mathrm{G} \beta$, and $13 \mathrm{G} \gamma$ subunits [8,9], provides the level of selectivity that is needed to generate the wide range of signals governed by G-proteins and their cognate GPCRs (Figure 1) [10-12]. 


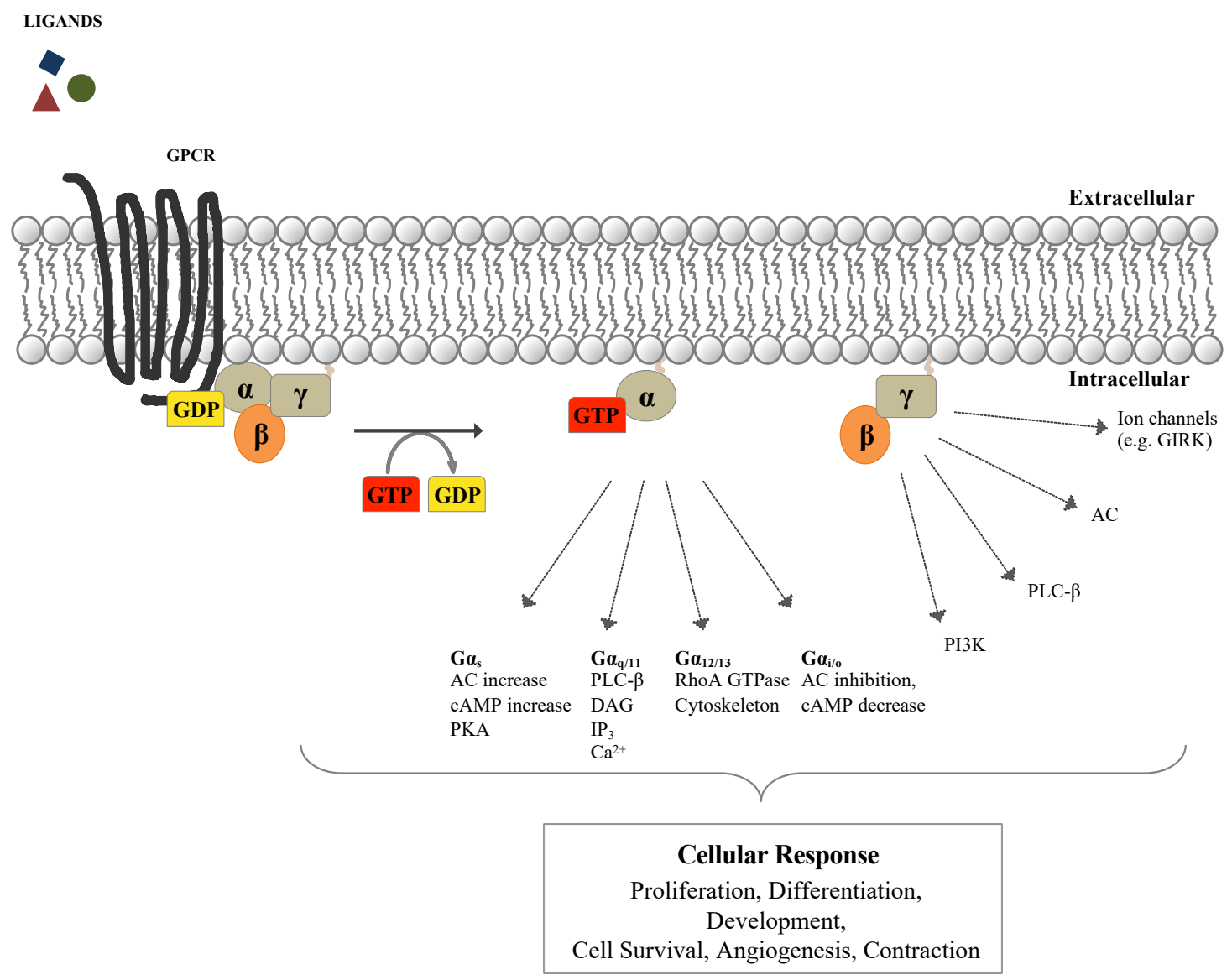

Figure 1. G-protein-coupled receptors signalosome. In the resting state, G-proteins are heterotrimers of alpha bound to guanosine diphosphate (GDP, yellow), beta, and gamma subunits. When activated by an extracellular ligand through G-protein coupled receptors (GPCRs, black), they undergo a conformational change that permits the GDP exchange with GTP (red) on G $\alpha$, which then dissociates from $\mathrm{G} \beta \gamma$. In the active state, G $\alpha$-GTP and G $\beta \gamma$ regulate various effectors. According to functional and structural homologies of their $\alpha$ subunit, heterotrimeric G-proteins are divided into four types $\left(\mathrm{G} \alpha_{\mathrm{s}}\right.$, $\mathrm{G} \alpha_{\mathrm{i} / \mathrm{o}}, \mathrm{G} \alpha_{\mathrm{q} / 11}$, and $\left.\mathrm{G} \alpha_{12 / 13}\right)$. Each $\mathrm{G} \alpha$ defines the unique $\mathrm{G} \alpha \beta \gamma$ mediated cellular responses [1,13-16]. $\mathrm{G} \alpha_{\mathrm{s}}$ and $\mathrm{G} \alpha_{\mathrm{i}}$ subfamily members are involved in the modulation of the intracellular second-messenger cAMP levels, either stimulating $\left(G_{s}\right)$ or inhibiting $\left(G_{i}\right)$ the production of cAMP by AC activity. $G \alpha_{q / 11}$ induces the activation of PLC- $\beta$, promoting the production of the intracellular messenger DAG and $\mathrm{IP}_{3}$ which activate the PKC and calcium signaling. $\mathrm{G} \alpha_{12 / 13}$ plays a role in the activation of the RhoA GTPase and of phospholipase D in regulating cell shape and motility $[14,17,18]$. Adenylyl cyclase (AC); cyclic adenosine monophosphate (cAMP); protein kinase A (PKA); phospholipase C $\beta$ (PLC- $\beta$ ); diacylglycerol (DAG); inositol $(1,4,5)$ trisphosphate $\left(\mathrm{IP}_{3}\right)$; protein kinase $\mathrm{C}(\mathrm{PKC})$; intracellular concentration of free $\mathrm{Ca}^{2+}\left(\mathrm{Ca}^{2+}\right)$; Ras homolog family member A GTPase (RhoA GTPase); phosphatidylinositol-3-kinase (PI3K); G-protein-gated inwardly rectifying potassium channels (GIRK).

The propagation of the GPCR signaling cascade is restricted by the Regulators of G-protein Signaling (RGS) proteins, which limit the active G $\alpha$ subunit lifetime and accelerate its GTP hydrolysis with a consequent re-association with the G $\beta \gamma$ dimer [19-24].

Here, we review the G $\beta$ subunits and their contribution to the etiology of rare human genetic conditions. In the last six years, the outbreak of Next Generation Sequencing (NGS) technologies has assisted us to reach the description of a tapestry of human genetic conditions caused by the pathogenic variants in $\mathrm{G} \beta$ subunits, and disease manifestations mainly involving neuronal and cardiac systems associated with ophthalmic pathology. 


\section{G $\beta$ Subunits: Genes and Proteins Structure}

The human genome contains five genes (GNB1 to GNB5) encoding the different G $\beta$ subunits [25]. Chromosomal locations, genes structure and exons content of each of the five subunits are summarized in Table 1 . The G $\beta_{1-4}$ subunits share between 80 and $90 \%$ sequence identity and are widely expressed throughout the tissues [26,27]; the $G \beta_{5}$ exhibits much less homology $(\sim 50 \%)$ and is preferentially expressed in the brain and nervous system [28], while the $G \beta_{5}$ longer isoform, $G \beta_{5} L$, has restricted expression in retinal photoreceptor outer segments $[9,29]$.

At the protein level, iconic is the beta-propeller structure of the $G \beta$ subunits, characterized by seven regular WD40-repeats [30] and a coiled coil domain at the N-terminus end. The WD40 domain is one of the most abundant and interacting domain in the eukaryotic proteome; each domain is approximately 40 amino acids long and is characterized by a conserved tryptophan (W)-aspartic (D) acid pair, hence the name WD40 [29,31]. With its $\beta$-propeller architecture, the WD40 domain provides extensive surface exposure for protein-protein or protein-DNA interaction, that coordinate downstream cellular events including signal transduction, autophagy, and apoptosis [32]. 
Table 1. Gene content and major features of the five genes encoding the G $\beta$ subunits. Gene names are reported according to the Hugo Gene Nomenclature Committee (HGNC, [33]); Ensembl gene and transcript IDs, information on transcript/protein length as well as number of exons were retrieved to the Ensembl 97 and Ensembl Genomes 44 release, and, finally, genomic coordinates are specified on the GRCh38.p13 genome assembly. Uniprot identifiers rely on the UniProt release 2019_06 (published July 3, 2019) [34]. MIM IDs and phenotype MIM numbers are as in OMIM (Online Mendelian Inheritance in Men) database.

\begin{tabular}{|c|c|c|c|c|c|c|c|c|c|c|c|c|c|c|}
\hline $\begin{array}{c}\text { Gene } \\
\text { Name } \\
\text { (HGNC) }\end{array}$ & Description & Ensembl ID & RefSeq ID & $\begin{array}{c}\text { Ensembl } \\
\text { Transcript ID }\end{array}$ & $\begin{array}{l}\text { Transcritp } \\
\text { Length } \\
\text { (bp) }\end{array}$ & $\begin{array}{l}\text { Protein } \\
\text { length } \\
\text { (aa) }\end{array}$ & Uniprot & $\begin{array}{l}\text { Cytogenetic } \\
\text { Location }\end{array}$ & $\begin{array}{l}\text { Genomic Coordinates } \\
\text { (GRCh38, from Ensembl) }\end{array}$ & Strand & $\begin{array}{l}\text { Nr. of } \\
\text { Exons }\end{array}$ & $\begin{array}{c}\text { Nr. of } \\
\text { Coding } \\
\text { Exons }\end{array}$ & $\begin{array}{c}\text { MIM } \\
\text { ID }\end{array}$ & $\begin{array}{c}\text { Phenotype } \\
\text { MIM } \\
\text { Number(s) }\end{array}$ \\
\hline GNB1 & $\begin{array}{c}\text { G protein } \\
\text { subunit beta } 1\end{array}$ & ENSG00000078369.18 & NM_002074 & ENST00000378609.9 & 3163 & 340 & P62873 & $1 \mathrm{p} 36.33$ & 1:1,785,285-1,891,117 & $\begin{array}{l}\text { reverse } \\
\text { strand }\end{array}$ & 12 & 9 & ${ }^{*} 139380$ & \#616973 \\
\hline GNB2 & $\begin{array}{c}\text { G protein } \\
\text { subunit beta } 2\end{array}$ & ENSG00000172354.10 & NM_005273 & ENST00000303210.9 & 1664 & 340 & Q6FHM2 & $7 \mathrm{q} 22.1$ & $7: 100,673,567-100,679,174$ & $\begin{array}{l}\text { forward } \\
\text { strand }\end{array}$ & 10 & 9 & ${ }^{*} 139390$ & - \\
\hline GNB3 & $\begin{array}{c}\text { G protein } \\
\text { subunit beta } 3\end{array}$ & ENSG00000111664.10 & NM_002075 & ENST00000229264.7 & 1923 & 340 & P16520 & $12 \mathrm{p} 13.31$ & $12: 6,840,211-6,847,393$ & $\begin{array}{c}\text { forward } \\
\text { strand }\end{array}$ & 11 & 9 & ${ }^{*} 139130$ & $\# 617024$ \\
\hline GNB4 & $\begin{array}{c}\text { G protein } \\
\text { subunit beta } 4\end{array}$ & ENSG00000114450.10 & NM_021629 & ENST00000232564.8 & 6315 & 340 & Q9HAV0 & $3 q 26.33$ & 3:179,396,088-179,451,476 & $\begin{array}{l}\text { reverse } \\
\text { strand }\end{array}$ & 10 & 9 & ${ }^{*} 610863$ & $\# 615185$ \\
\hline GNB5 & $\begin{array}{c}\text { G protein } \\
\text { subunit beta } 5\end{array}$ & ENSG00000069966.18 & NM_006578 & ENST00000358784.11 & 1735 & 353 & O14775 & $15 \mathrm{q} 21.2$ & $15: 52,122,206-52,180,001$ & $\begin{array}{l}\text { reverse } \\
\text { strand }\end{array}$ & 11 & 11 & $* 604447$ & $\begin{array}{l}\# 617173, \\
\# 617182\end{array}$ \\
\hline
\end{tabular}




\section{G $\beta$ proteins and Human Diseases}

\subsection{G Protein Subunit Beta $1\left(G N B 1, G \beta_{1}\right)$}

In humans, heterozygous GNB1 (MIM 139380) missense, splice-site and frameshift pathogenic variants cause an autosomal dominant neurodevelopmental disorder, named MRD42 (Mental Retardation, Autosomal Dominant 42; MIM\#616973). The phenotype observed across individuals with MRD42 include global developmental delay (GDD)/intellectual disability (ID), hypotonia often associated with limb hypertonia, various types of seizures, and poor overall growth [35-37]. Strabismus, nystagmus, cortical visual impairment, attention deficit hyperactivity disorder, and autistic features may also be present [38]. Less frequent and variable symptoms are ataxia, dystonia, hydronephrosis, acute lymphoblastic leukemia [35,37-40], and cutaneous mastocytosis [41,42].

GNB1 was found as one of the five genes deleted in five patients with 200 to 823-kb overlapping interstitial deletions of chromosome 1p36.33 (MIM\#607872) affected by ID, developmental delay, seizures and muscular hypotonia together with characteristic dysmorphic features, and behavior abnormalities [43,44]. Functional evidence of GNB1 involvement in neurodevelopmental delay is also corroborated by the study of homozygous Gnb1 mutant mice, demonstrating that Gnb1 is essential for normal embryonic neurogenesis. Forty percent of Gnb1 knock-out embryos were neonatal lethal and showed defects in neural tube closure and neural progenitor cell proliferation associated to exencephaly (Table 2); embryos without neural tube defects presented microencephaly and died after birth [45]. Moreover, Gnb1 heterozygous mice exhibited abnormal retina morphology with progressive degeneration (http://www.informatics.jax.org/marker/MGI:95781), thus supporting the ophthalmic manifestations reported in MRD42 affected individuals.

To date, twenty eight de novo and four with undefined inheritance GNB1 variants have been reported in 53 affected individuals; of these 28 are missense, 2 frameshift, and 2 splice-site variants (Figure 2) [35-42].

Overall, 24/32 ( $75 \%)$ GNB1 variants affect residues coded by exon $6(11 / 24)$ or exon $7(13 / 24)$ (Figure 2). This small part of the gene encodes for a protein region forming the G $\alpha$ and G $\beta \gamma$ interaction surface [46]. Accordingly, three GNB1 likely benign missense variants (c.88C $>$ T, p.(Leu30Phe); c.272A > G, p.(His91Arg); c.1009A>C, p.(Lys337Gln) are located distantly from the interaction site and no impaired $G \beta_{1}$ functionality has been shown [40].

\subsection{G Protein Subunit Beta $2\left(G N B 2, G \beta_{2}\right)$}

Heterozygous GNB2 (MIM 139390) c.155G>T, p.(Arg52Leu) (Figure 2) missense variant has been identified in 11 individuals of a family composed of 25 members. Carriers were affected by an autosomal dominant form of Sinus Node Dysfunction (SND) occurring in combination with atrioventricular conduction dysfunction and atrial fibrillation, in the absence of heart structural problems [47]. Crystal structure model of the mammalian G-protein-coupled inwardly rectifying potassium channel 2 (GIRK2) with $\beta_{1} \gamma_{2}$ G-protein complex, showed that Arg52 lays at the binding interface with GIRK [48], a data confirmed also for GIRK1/4 and G $\beta_{2}$ [47]. Therefore, the presence of the mutant residue is predicted to decrease the steric interaction at the GIRK-G $\beta_{2}$ surface. Functional studies revealed that the heterozygous variant has an impact on the rectification of the GIRK channel with a consequent increase of $\mathrm{ACh}$-activated $\mathrm{K}^{+}$current $\left(\mathrm{I}_{\mathrm{K}, \mathrm{ACh}}\right)$ [47], thus displaying a gain-of-function effect. Of note, the cardiac GIRK channels are directly switched on by the G $\beta \gamma$ units and are involved in the negative chronotropic effect of the parasympathetic nervous system, thus controlling heart rate and cellular electrical excitability $[49,50]$. A recent study of 52 unrelated patients with idiopathic SND uncovered a nonsynonymous substitution (c.303G>C, p.(Trp101Cys)) in the KCNJ5 gene, encoding the Kir3.4 subunit of the GIRK channel. The mutation leads to a sustained activation of the cardiac GIRK channel [51]. Finally, further examples of the connection between GNB2 and heart disease are provided by the Gnb2 knock-out mice, generated by the International Mouse Phenotyping Consortium (IMPC; https://www.mousephenotype.org/data/genes/MGI:95784) [52]. Null Gnb2 mice showed an increased 
heart rate, and abnormal electrocardiogram line, revealing shortened RR interval, PQ interval, and ST segment (Table 2).
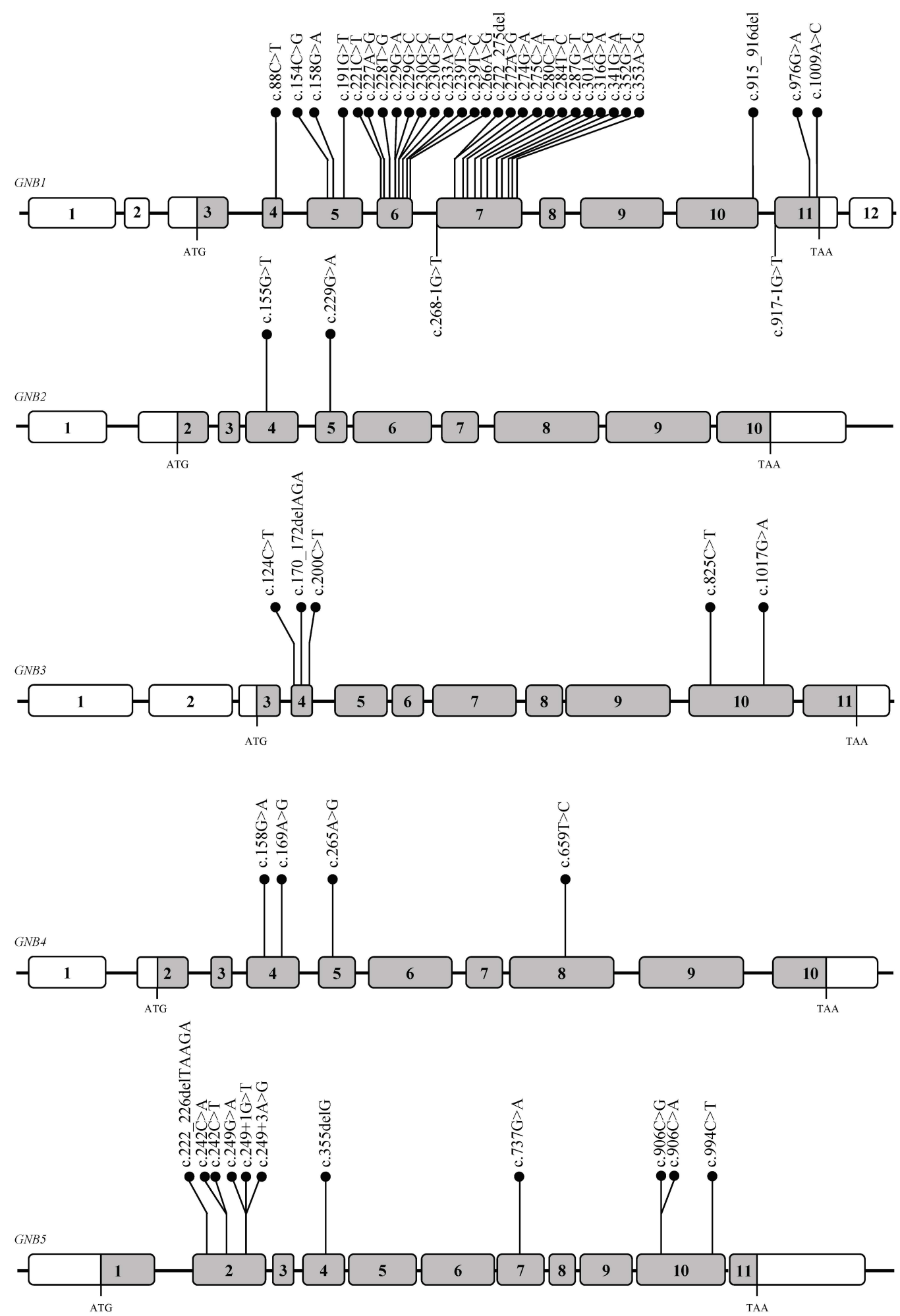

Figure 2. Variants distribution across the entire GNB1-GNB5 genes. Genomic coordinates are specified on the GRCh37.p13 genome assembly. Coding exons are indicated by grey boxes, while untranslated regions are displayed in white. Variants annotations refer to NM_002074 for GNB1, NM_005273 for GNB2, NM_002075 for GNB3, NM_021629 for GNB4, NM_006578 for GNB5. 
Additionally, an individual with global developmental delay, intellectual disability, muscle hypotonia and dysmorphisms carrying a de novo GNB2 missense variant (c.229G >A, p.(Gly77Arg)) (Figure 2), predicted to impair protein function, was recently described in [53]. This study highlights that GNB2 variants not only associate to cardiac manifestations, but cause developmental delay too [53].

Table 2. GNB genes have been studied in different model organisms. The table lists phenotypic manifestations resulting from complete (knock-out, KO) or partial (knock-down, KD) lack of each of the five GNB genes. "HET" refers to mouse models carrying only one functional copy of the gene, and "Dup" concerns the presence of three copies. Of note, in Zebrafish each of the genes has two paralogs, as a result of an ancient genome duplication event. In Drosophila melanogaster and C. elegans only two definite homologues have been identified, one corresponding to human GNB1-4 and one corresponding to human GNB5, in each species. NA indicates "Not Available" model.

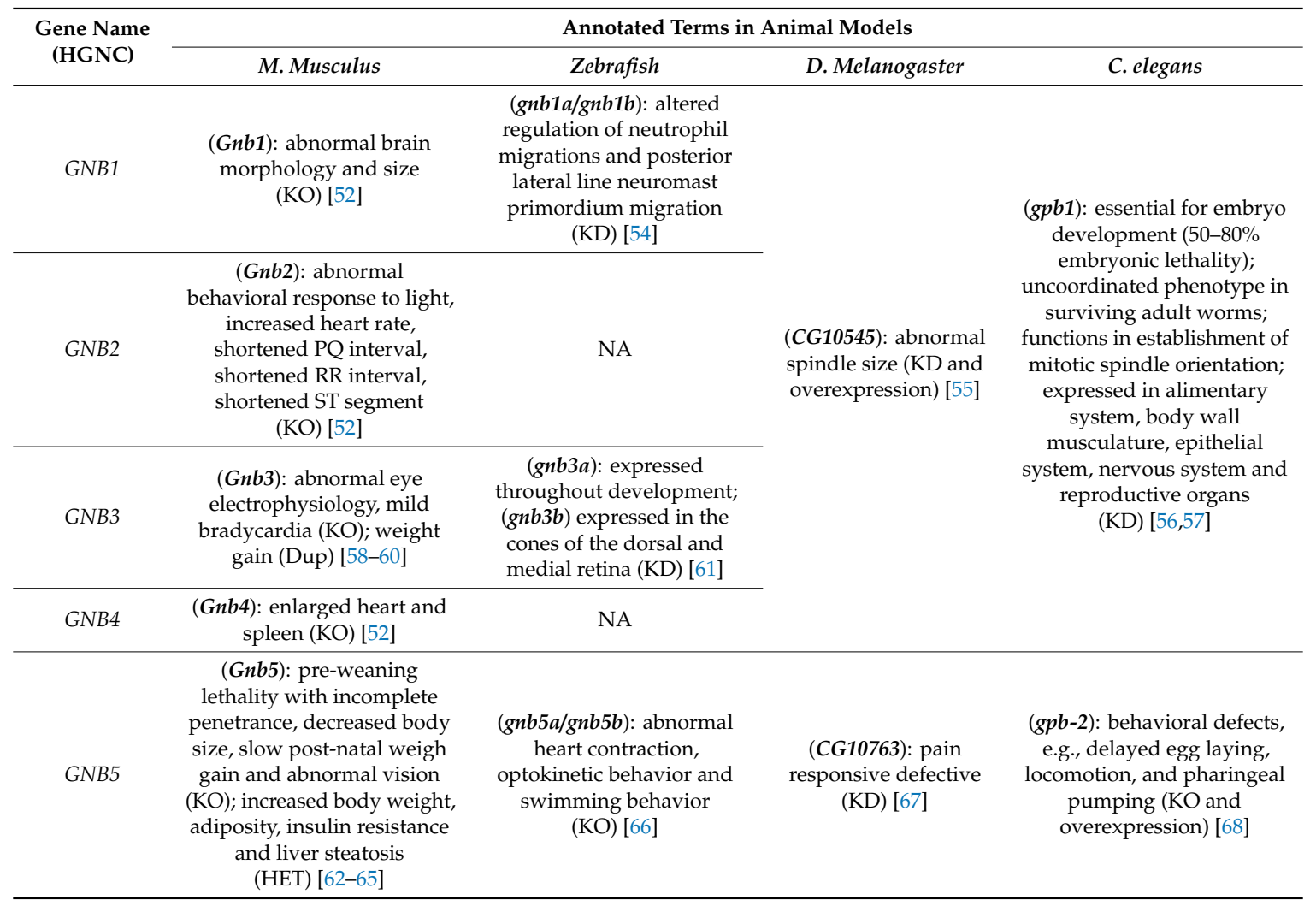

\subsection{G Protein Subunit Beta $3\left(G N B 3, G \beta_{3}\right)$}

Homozygous and compound heterozygous GNB3 (MIM 139130) disease-causing variants were described in three individuals of a large Lebanese-Armenian family affected by Congenital Stationary Night Blindness type 1H (CSNB1H, MIM\#617024) [8] and in a fourth sporadic case [69]. CSNB refers to a group of clinically heterogeneous retinal disorders caused by genetic defects of the retinoid metabolism in the retinal pigment epithelium (RPE), phototransduction, or signal transmission through the bipolar cells (BCs) $[70,71]$. Based on BCs ability to either initiate or terminate light stimuli, BCs can be either ON- or OFF-type. Specifically, while cone photoreceptors can connect both ON- and OFF-BCs, the rods are served largely by the ON-BCs [70].

The three first identified GNB3 variants lie in the first (c.170_172delAGA, p.(Lys57del); c.200C >T, p.(Ser67Phe)) and seventh (c.1017G $>A$, p.(Trp339*)) WD40 repeat of the encoded G $\beta_{3}$ protein, respectively (Figure 2). Homology model studies of $G \beta_{3}$ protein structure, pointed out that each variant would impact interactions abilities as well as the formation of effective G-protein complexes [8]. A fourth GNB3 variant (c.124C $>$ T, p. (Arg42Ter)) was found in a patient with distinct early-onset inherited retinal disease, characterized by nystagmus, normal funduscopic exam, full-field electroretinography 
abnormalities, and mild disturbance of the central macula [69]. The Arg42 variant, located in exon 4 of the gene, gives rise to a premature stop codon, which is expected to be a substrate of the nonsense-mediate decay pathway [69].

$\mathrm{G} \beta_{3}$ is expressed at higher levels in the eyes, in particular in the cone photoreceptors and ON-BCs of the retina in mammals and additional species [72-74]. In the eye, $G \beta_{3}$ modulates cone transducing function and cone and rod ON-bipolar signaling [8].

Similar to humans [8], abnormal light ON bipolar response and reduced cone sensitivity was also found in a Gnb3 knock-out mouse model [75,76], while retinopathy globe enlarged (rge) phenotype was reported in the chicken carrying a 3-bp homozygous deletion of the GNB3 homolog [77]. Interestingly, ablation of the $G n b 3$ gene in mice causes mild bradycardia [58], thus suggesting a possible additional role of GNB3 in heart rate regulation.

Beyond the role of GNB3 pathogenic variants in the etiology of CSNB1H, [8] Siffert and colleagues [78], described the c.825C $>\mathrm{T}$ (rs5443) polymorphism in exon 10 of the gene as linked to the expression of a shortened splice variant, $G \beta_{3} \mathrm{~s}$, whose translated protein is characterized by the deletion of 41 amino acids, responsible of enhanced G-proteins signal transduction [78]. The c. $825 \mathrm{C}>\mathrm{T}$ polymorphism is associated with an increased risk of hypertension [78-81], obesity [59,82], diabetes [83], metabolic syndrome component [84,85], depression [86,87], seasonal variations in mood and behaviors [88], functional dyspepsia [89,90], stroke [91,92], arrhythmia [93], coronary artery disease [94,95], and other cardiovascular phenotypes [96-99]. In addition, duplication and overexpression of GNB3 gene is responsible for a syndromic form of childhood obesity $[59,100]$.

\subsection{G Protein Subunit Beta (GNB4, G $\left.\beta_{4}\right)$}

Heterozygous pathogenic variants in GNB4 gene (MIM 610863) (Figure 2) have been reported as causative of intermediate Charcot-Marie-Tooth disease F (CMTDIF, MIM\#615185), an autosomal dominant form of CMT. CMT is a neurologic disorder characterized by progressive distal muscle atrophy and weakness and variable nerve conduction velocities ranging from the demyelinating to the axonal range [101]. Heterozygous c.158G >A, p.(Gly53Asp) GNB4 missense variant was reported in six affected family members. An unrelated case carried the heterozygous c.265A $>G ; p$.(Lys89Glu) de novo missense variant [101]. The pathogenicity of the variants and the importance of GPCR signaling in peripheral-nerve function in humans were supported by the reduced $G \beta_{4}$ immunostaining in the axon and Schwann cells of peripheral nerves of affected individuals. Moreover, in vitro studies demonstrated that both variants altered the bradykinin induced GPCR signaling [101].

More recently, the description of one Czech patient presenting the c.169A>G, p.(Lys57Glu) variant [102], and one Japanese family, for which axonal neuropathy has been reported, and segregating with c.659T>C, p.(Gln220Arg) [103], confirmed the pathogenic role of GNB4 as causal gene of CMTIDF.

All the GNB4 pathogenic variants described so far are located in the first (p.(Gly53Asp) and p.(Lys57Glu)) [101,102], in the second (p.(Lys89Glu)) [101], and in the fifth WD40 domain (p.(Gln220Arg)) [103], respectively (Figure 2). The Gly53 and Lys89 are important residues for the architecture of the WD40 $\beta$-propeller structure [104]. Functional characterization of p.(Gly53Asp) and p.(Lys89Glu) showed an impaired GPCR signaling via a dominant-negative effect, and resulting in reduced PLC $\beta_{2}$ activity $[104,105]$ followed by inhibition of $\mathrm{IP}_{3}$ production and moderate increase in cytosolic calcium $\left(\mathrm{Ca}^{2+}\right)$ level $[101,106]$, a universal second messenger that regulates the transmission of the depolarizing signal and neuronal synaptic activity.

Similar to $G \beta_{2}, G \beta_{4}$ is known to influence the activity of the cardiac GIRK channel, which regulates the heart rhythm through the acetylcholine-dependent activation of the muscarinic M2-receptor present in the sinoatrial node [107-110]. Although this gene has been reported in human hereditary neuropathy, genome-wide association studies have revealed association of the GNB4 locus with variation in heart rate $[47,111,112]$. This suggests that GNB4 variation may also impact heart rate. 


\subsection{G Protein Subunit Beta (GNB5, G $\left.\beta_{5}\right)$}

The GNB5 gene (MIM 604447), encoding the subunit $\beta 5$ of the heterotrimeric G-proteins, is a divergent member of the $G \beta$ family with distinct biochemical properties. Differently from $G \beta_{1-4}, G \beta_{5}$ forms irreversible dimer with the G-protein $\gamma$-like (GGL) domain [113] present in the R7 regulator group of G-protein signaling proteins (R7 RGS) [64,114-119]. Interaction of the GGL domain and the atypical $G \beta_{5}$ is a general requirement for stabilization of the whole R7 protein subfamily.

Homozygous or compound heterozygous variants in the GNB5 gene have been associated with either IDDCA (Intellectual Developmental Delay with Cardiac Arrhythmia, MIM\#617173) or LADCI (Language delay and ADHD/Cognitive Impairment with or without cardiac arrhythmia, MIM\#617182) human syndromes [66,120-125]. Homozygous carriers of the recurrent missense variant c. $242 \mathrm{C}>\mathrm{T}$, p.(Ser81Leu), present with LADCI syndrome, characterized by mild intellectual disability in combination with language delay, attention-deficit/hyperactivity disorder, with or without cardiac arrhythmia $[66,125]$. The substitution of the evolutionary conserved Serine 81 with the hydrophobic Leucine was predicted to compromise protein folding and/or stability as well as impair the binding kinetics of RGS proteins [66] and their capacity to deactivate G-protein signaling initiated by dopamine receptors [125]. By contrast, homozygous or compound heterozygous carriers of GNB5 Loss of Function alleles presented IDDCA, whose phenotypic spectrum includes epileptic seizures, severe intellectual disability, drastic impairment in speech and language skills, vision problems (which mainly include nystagmus and retinal abnormalities), hypotonia, and sick sinus syndrome [66,120-124]. Among the GNB5 pathogenic variants described so far [66,120-125], a mutational hot spot in exon 2, encoding the first WD40 domain and containing $58 \%$ of described variants, has been identified (Figure 2). The evidence of the GNB5 involvement in neuronal and cardiac signaling was confirmed in Gnb5-null zebrafish and mouse models that resulted in neuronal and cardiac phenotypes reminiscent of those of IDDCA patients $[63,66,126,127]$.

Gnb5-null mouse models displayed marked neurobehavioral abnormalities, impaired gait and motor learning, hyperactivity [62-65], defective visual adaptation with perturbed development and functioning of retinal bipolar cells [127-129]. Moreover, targeted deletion of one or two copies of the Gnb5 gene had distinct effects on body weight and behavior in mice [62]. Although the cardiac phenotype of Gnb5-null mouse has never been studied, it is interesting to observe that bradycardia and heart rate responses to the cholinergic stimulation were exhibited by mice lacking Rgs6, the Gnb5-dependent RGS protein in the heart [130-132]. The gnb5 knock-out zebrafish model also recapitulated the phenotypic spectrum of affected individuals, highlighting the involvement of GNB5 in the control of motor capacity, vision and heart rate [66]. Several model organisms have been characterized regarding GNB5; information of additional animal models is included in Table 2.

\section{Concluding Remarks}

Heterotrimeric G-protein signaling is one of the most important mechanisms of cellular communication. They are involved in a vast array of cellular processes required for the normal growth and development of cells. The G $\beta$ proteins, representing one of the components of the heterotrimeric G-proteins, are specifically expressed in different tissues and elicit a wide range of specialized cellular responses. It is not surprising that mutations altering the G-proteins function, compromise cellular responses and associate with aberrant physiological functions, resulting in disease.

We anticipate that unravelling the role of $G \beta$ proteins in neurodevelopmental and cardiac conditions may help to provide targeted strategies to effectively modulate their pathogenesis and to shed light on possible future therapeutic approach.

Author Contributions: N.M. and G.M. conceived this review. N.M. and P.D.N. reviewed the literature and wrote the manuscript along with G.M. All authors contributed to the final version of the manuscript.

Funding: This research was funded by the Italian Ministry of Health (Ricerca Corrente), the Daunia Plast and Stuppiello's Family (Private Donors) to GM. 
Acknowledgments: We thank Utsa Bhaduri for editing the whole text for English grammar, word choice and sentence construction.

Conflicts of Interest: The authors declare no conflict of interest.

\section{References}

1. Fredriksson, R.; Lagerstrom, M.C.; Lundin, L.G.; Schioth, H.B. The G-protein-coupled receptors in the human genome form five main families. Phylogenetic analysis, paralogon groups, and fingerprints. Mol. Pharm. 2003, 63, 1256-1272. [CrossRef] [PubMed]

2. Kamato, D.; Burch, M.L.; Osman, N.; Zheng, W.; Little, P.J. Therapeutic implications of endothelin and thrombin G-protein-coupled receptor transactivation of tyrosine and serine/threonine kinase cell surface receptors. J. Pharm. 2013, 65, 465-473. [CrossRef] [PubMed]

3. de Oliveira, P.G.; Ramos, M.L.S.; Amaro, A.J.; Dias, R.A.; Vieira, S.I. Gi/o-Protein coupled receptors in the aging brain. Front. Aging Neurosci. 2019, 11, 89. [CrossRef] [PubMed]

4. Lagerstrom, M.C.; Schioth, H.B. Structural diversity of G protein-coupled receptors and significance for drug discovery. Nat. Rev. Drug Discov. 2008, 7, 339-357. [CrossRef]

5. Pierce, K.L.; Premont, R.T.; Lefkowitz, R.J. Seven-transmembrane receptors. Nat. Rev. Mol. Cell Biol. 2002, 3, 639-650. [CrossRef]

6. Gilman, A.G. G proteins: Transducers of receptor-generated signals. Annu. Rev. Biochem. 1987, 56, 615-649. [CrossRef]

7. Smrcka, A.V. G protein $\beta \gamma$ subunits: Central mediators of G protein-coupled receptor signaling. Cell Mol. Life Sci. 2008, 65, 2191-2214. [CrossRef]

8. Vincent, A.; Audo, I.; Tavares, E.; Maynes, J.T.; Tumber, A.; Wright, T.; Li, S.; Michiels, C.; Consortium, G.N.B.; Condroyer, $\mathrm{C}$; ; et al. Biallelic mutations in GNB3 cause a unique form of autosomal-recessive congenital stationary night blindness. Am. J. Hum. Genet. 2016, 98, 1011-1019. [CrossRef]

9. Watson, A.J.; Aragay, A.M.; Slepak, V.Z.; Simon, M.I. A novel form of the G protein $\beta$ subunit G $\beta 5$ is specifically expressed in the vertebrate retina. J. Biol. Chem. 1996, 271, 28154-28160. [CrossRef]

10. Khan, S.M.; Sleno, R.; Gora, S.; Zylbergold, P.; Laverdure, J.P.; Labbe, J.C.; Miller, G.J.; Hebert, T.E. The expanding roles of $G \beta \gamma$ subunits in $G$ protein-coupled receptor signaling and drug action. Pharm. Rev. 2013, 65, 545-577. [CrossRef]

11. Dupre, D.J.; Robitaille, M.; Rebois, R.V.; Hebert, T.E. The role of G $\beta \gamma$ subunits in the organization, assembly, and function of GPCR signaling complexes. Annu. Rev. Pharm. Toxicol. 2009, 49, 31-56. [CrossRef] [PubMed]

12. Robishaw, J.D.; Berlot, C.H. Translating G protein subunit diversity into functional specificity. Curr. Opin. Cell Biol. 2004, 16, 206-209. [CrossRef] [PubMed]

13. Azzi, M.; Charest, P.G.; Angers, S.; Rousseau, G.; Kohout, T.; Bouvier, M.; Pineyro, G. B-arrestin-mediated activation of MAPK by inverse agonists reveals distinct active conformations for $\mathrm{G}$ protein-coupled receptors. PNAS Proc. Natl. Acad. Sci. 2003, 100, 11406-11411. [CrossRef] [PubMed]

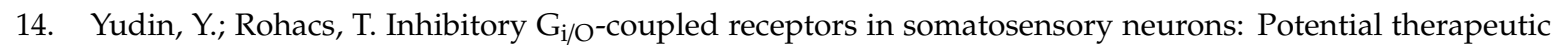
targets for novel analgesics. Mol. Pain 2018, 14. [CrossRef] [PubMed]

15. Rajagopal, S.; Kim, J.; Ahn, S.; Craig, S.; Lam, C.M.; Gerard, N.P.; Gerard, C.; Lefkowitz, R.J. B-arrestin- but not G protein-mediated signaling by the "decoy" receptor CXCR7. PNAS Proc. Natl. Acad. Sci. 2010, 107, 628-632. [CrossRef]

16. Rosenbaum, D.M.; Rasmussen, S.G.; Kobilka, B.K. The structure and function of G-protein-coupled receptors. Nature 2009, 459, 356-363. [CrossRef]

17. Nobles, M.; Benians, A.; Tinker, A. Heterotrimeric G proteins precouple with G protein-coupled receptors in living cells. PNAS Proc. Natl Acad Sci. 2005, 102, 18706-18711. [CrossRef]

18. Milligan, G.; Kostenis, E. Heterotrimeric G-proteins: A short history. Br. J. Pharm. 2006, 147, S46-S55. [CrossRef]

19. Hepler, J.R.; Berman, D.M.; Gilman, A.G.; Kozasa, T. RGS4 and GAIP are GTPase-activating proteins for $\mathrm{G}_{\mathrm{q} \alpha}$ and block activation of phospholipase $\mathrm{C} \beta$ by $\gamma$-thio-GTP-G $\mathrm{q}_{\alpha}$. PNAS Proc. Natl. Acad. Sci. 1997, 94, 428-432. [CrossRef]

20. Kozasa, T.; Jiang, X.; Hart, M.J.; Sternweis, P.M.; Singer, W.D.; Gilman, A.G.; Bollag, G.; Sternweis, P.C. P115

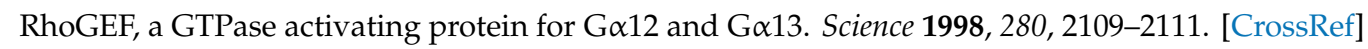


21. Hunt, T.W.; Fields, T.A.; Casey, P.J.; Peralta, E.G. RGS10 is a selective activator of G $\alpha_{\mathrm{i}}$ GTPase activity. Nature 1996, 383, 175-177. [CrossRef] [PubMed]

22. Berman, D.M.; Wilkie, T.M.; Gilman, A.G. GAIP and RGS4 are GTPase-activating proteins for the $G_{i}$ subfamily of $\mathrm{G}$ protein $\alpha$ subunits. Cell 1996, 86, 445-452. [CrossRef]

23. De Vries, L.; Zheng, B.; Fischer, T.; Elenko, E.; Farquhar, M.G. The regulator of G protein signaling family. Annu. Rev. Pharm. Toxicol. 2000, 40, 235-271. [CrossRef] [PubMed]

24. Neer, E.J. Heterotrimeric G proteins: Organizers of transmembrane signals. Cell 1995, 80, 249-257. [CrossRef]

25. Downes, G.B.; Gautam, N. The G protein subunit gene families. Genomics 1999, 62, 544-552. [CrossRef] [PubMed]

26. Lindorfer, M.A.; Myung, C.S.; Savino, Y.; Yasuda, H.; Khazan, R.; Garrison, J.C. Differential activity of the G protein $\beta 5 \gamma 2$ subunit at receptors and effectors. J. Biol. Chem. 1998, 273, 34429-34436. [CrossRef] [PubMed]

27. Gautam, N.; Downes, G.B.; Yan, K.; Kisselev, O. The G-protein $\beta \gamma$ complex. Cell Signal. 1998, 10, 447-455. [CrossRef]

28. Howlett, A.C.; Gray, A.J.; Hunter, J.M.; Willardson, B.M. Role of molecular chaperones in G protein $\beta 5 /$ regulator of $G$ protein signaling dimer assembly and $G$ protein $\beta \gamma$ dimer specificity. J. Biol. Chem. 2009, 284, 16386-16399. [CrossRef]

29. Watson, A.J.; Katz, A.; Simon, M.I. A fifth member of the mammalian G-protein $\beta$-subunit family. Expression in brain and activation of the $\beta 2$ isotype of phospholipase C. J. Biol. Chem. 1994, 269, 22150-22156.

30. Li, D.; Roberts, R. WD-repeat proteins: Structure characteristics, biological function, and their involvement in human diseases. Cell Mol. Life Sci. 2001, 58, 2085-2097. [CrossRef]

31. Sondek, J.; Bohm, A.; Lambright, D.G.; Hamm, H.E.; Sigler, P.B. Crystal structure of a G-protein $\beta \gamma$ dimer at 2.1A resolution. Nature 1996, 379, 369-374. [CrossRef] [PubMed]

32. Jain, B.P.; Pandey, S. WD40 repeat proteins: Signalling scaffold with diverse functions. Protein J. 2018, 37, 391-406. [CrossRef] [PubMed]

33. Yates, B.; Braschi, B.; Gray, K.A.; Seal, R.L.; Tweedie, S.; Bruford, E.A. Genenames.org: the HGNC and VGNC resources in 2017. Nucleic Acids Res. 2017, 45, D619-D625. [CrossRef] [PubMed]

34. UniProt Consortium. UniProt: a worldwide hub of protein knowledge. Nucleic Acids Res. 2019, 47, D506-D515. [CrossRef]

35. Steinrucke, S.; Lohmann, K.; Domingo, A.; Rolfs, A.; Baumer, T.; Spiegler, J.; Hartmann, C.; Munchau, A. Novel GNB1 missense mutation in a patient with generalized dystonia, hypotonia, and intellectual disability. Neurol. Genet. 2016, 2, e106. [CrossRef]

36. Endo, W.; Ikemoto, S.; Togashi, N.; Miyabayashi, T.; Nakajima, E.; Hamano, S.I.; Shibuya, M.; Sato, R.; Takezawa, Y.; Okubo, Y.; et al. Phenotype-genotype correlations in patients with GNB1 gene variants, including the first three reported Japanese patients to exhibit spastic diplegia, dyskinetic quadriplegia, and infantile spasms. Brain Dev. 2019. [CrossRef]

37. Brett, M.; Lai, A.H.; Ting, T.W.; Tan, A.M.; Foo, R.; Jamuar, S.; Tan, E.C. Acute lymphoblastic leukemia in a child with a de novo germline gnb1 mutation. Am. J. Med. Genet. A 2017, 173, 550-552. [CrossRef]

38. Petrovski, S.; Kury, S.; Myers, C.T.; Anyane-Yeboa, K.; Cogne, B.; Bialer, M.; Xia, F.; Hemati, P.; Riviello, J.; Mehaffey, M.; et al. Germline de novo mutations in GNB1 cause severe neurodevelopmental disability, hypotonia, and seizures. Am. J. Hum. Genet. 2016, 98, 1001-1010. [CrossRef]

39. Jones, H.F.; Morales-Briceno, H.; Barwick, K.; Lewis, J.; Sanchis-Juan, A.; Raymond, F.L.; Stewart, K.; Waugh, M.C.; Mahant, N.; Kurian, M.A.; et al. Myoclonus-dystonia caused by GNB1 mutation responsive to deep brain stimulation. Mov. Disord. 2019, 34, 1079-1080. [CrossRef]

40. Lohmann, K.; Masuho, I.; Patil, D.N.; Baumann, H.; Hebert, E.; Steinrucke, S.; Trujillano, D.; Skamangas, N.K.; Dobricic, V.; Huning, I.; et al. Novel GNB1 mutations disrupt assembly and function of G protein heterotrimers and cause global developmental delay in humans. Hum. Mol. Genet. 2017, 26, 1078-1086. [CrossRef]

41. Hemati, P.; Revah-Politi, A.; Bassan, H.; Petrovski, S.; Bilancia, C.G.; Ramsey, K.; Griffin, N.G.; Bier, L.; Cho, M.T.; Rosello, M.; et al. Refining the phenotype associated with GNB1 mutations: Clinical data on 18 newly identified patients and review of the literature. Am. J. Med. Genet. A 2018, 176, 2259-2275. [CrossRef] [PubMed]

42. Szczaluba, K.; Biernacka, A.; Szymanska, K.; Gasperowicz, P.; Kosinska, J.; Rydzanicz, M.; Ploski, R. Novel GNB1 de novo mutation in a patient with neurodevelopmental disorder and cutaneous mastocytosis: Clinical report and literature review. Eur. J. Med. Genet. 2018, 61, 157-160. [CrossRef] [PubMed] 
43. Rosenfeld, J.A.; Crolla, J.A.; Tomkins, S.; Bader, P.; Morrow, B.; Gorski, J.; Troxell, R.; Forster-Gibson, C.; Cilliers, D.; Hislop, R.G.; et al. Refinement of causative genes in monosomy 1p36 through clinical and molecular cytogenetic characterization of small interstitial deletions. Am. J. Med. Genet. Part A 2010, 152A, 1951-1959. [CrossRef] [PubMed]

44. Shaffer, L.G.; Lupski, J.R. Molecular mechanisms for constitutional chromosomal rearrangements in humans. Annu. Rev. Genet. 2000, 34, 297-329. [CrossRef]

45. Okae, H.; Iwakura, Y. Neural tube defects and impaired neural progenitor cell proliferation in G $\beta 1$-deficient mice. Dev. Dyn. 2010, 239, 1089-1101. [CrossRef]

46. Ford, C.E.; Skiba, N.P.; Bae, H.; Daaka, Y.; Reuveny, E.; Shekter, L.R.; Rosal, R.; Weng, G.; Yang, C.S.; Iyengar, R.; et al. Molecular basis for interactions of $G$ protein $\beta \gamma$ subunits with effectors. Science 1998, 280, 1271-1274. [CrossRef]

47. Stallmeyer, B.; Kuss, J.; Kotthoff, S.; Zumhagen, S.; Vowinkel, K.; Rinne, S.; Matschke, L.A.; Friedrich, C.; Schulze-Bahr, E.; Rust, S.; et al. A mutation in the G-protein gene GNB2 causes familial sinus node and atrioventricular conduction dysfunction. Circ. Res. 2017, 120, e33-e44. [CrossRef]

48. Whorton, M.R.; MacKinnon, R. X-ray structure of the mammalian GIRK2- $\beta \gamma$ G-protein complex. Nature 2013, 498, 190-197. [CrossRef]

49. Gehrmann, J.; Meister, M.; Maguire, C.T.; Martins, D.C.; Hammer, P.E.; Neer, E.J.; Berul, C.I.; Mende, U. Impaired parasympathetic heart rate control in mice with a reduction of functional $G$ protein $\beta \gamma$-subunits. Am. J. Physiol. Heart Circ. Physiol. 2002, 282, H445-H456. [CrossRef]

50. Logothetis, D.E.; Kurachi, Y.; Galper, J.; Neer, E.J.; Clapham, D.E. The $\beta \gamma$ subunits of GTP-binding proteins activate the muscarinic $\mathrm{K}^{+}$channel in heart. Nature 1987, 325, 321-326. [CrossRef]

51. Kuss, J.; Stallmeyer, B.; Goldstein, M.; Rinne, S.; Pees, C.; Zumhagen, S.; Seebohm, G.; Decher, N.; Pott, L.; Kienitz, M.C.; et al. Familial sinus node disease caused by a gain of GIRK (G-protein activated inwardly rectifying $\mathrm{K}^{+}$channel) channel function. Circ. Genom. Precis. Med. 2019, 12, e002238. [CrossRef] [PubMed]

52. Dickinson, M.E.; Flenniken, A.M.; Ji, X.; Teboul, L.; Wong, M.D.; White, J.K.; Meehan, T.F.; Weninger, W.J.; Westerberg, H.; Adissu, H.; et al. High-throughput discovery of novel developmental phenotypes. Nature 2016, 537, 508-514. [CrossRef] [PubMed]

53. Fukuda, T.; Hiraide, T.; Yamoto, K.; Nakashima, M.; Kawai, T.; Yanagi, K.; Ogata, T.; Saitsu, H. Exome reports A de novo GNB2 variant associated with global developmental delay, intellectual disability, and dysmorphic features. Eur. J. Med. Genet. 2019, 103804. [CrossRef] [PubMed]

54. Ke, W.; Ye, D.; Mersch, K.; Xu, H.; Chen, S.; Lin, F. Gß1 is required for neutrophil migration in zebrafish. Dev. Biol. 2017, 428, 135-147. [CrossRef]

55. Fuse, N.; Hisata, K.; Katzen, A.L.; Matsuzaki, F. Heterotrimeric G proteins regulate daughter cell size asymmetry in Drosophila neuroblast divisions. Curr. Biol. 2003, 13, 947-954. [CrossRef]

56. Simmer, F.; Moorman, C.; van der Linden, A.M.; Kuijk, E.; van den Berghe, P.V.; Kamath, R.S.; Fraser, A.G.; Ahringer, J.; Plasterk, R.H. Genome-wide RNAi of C. elegans using the hypersensitive $r r f-3$ strain reveals novel gene functions. PLoS Biol. 2003, 1, E12. [CrossRef]

57. Dubaj Price, M.; Hurd, D.D. WormBase: A model organism database. Med. Ref. Serv. Q 2019, 38, 70-80. [CrossRef]

58. Ye, Y.; Sun, Z.; Guo, A.; Song, L.S.; Grobe, J.L.; Chen, S. Ablation of the GNB3 gene in mice does not affect body weight, metabolism or blood pressure, but causes bradycardia. Cell Signal. 2014, 26, 2514-2520. [CrossRef]

59. Ozdemir, A.C.; Wynn, G.M.; Vester, A.; Weitzmann, M.N.; Neigh, G.N.; Srinivasan, S.; Rudd, M.K. GNB3 overexpression causes obesity and metabolic syndrome. PLoS ONE 2017, 12, e0188763. [CrossRef]

60. Goldlust, I.S.; Hermetz, K.E.; Catalano, L.M.; Barfield, R.T.; Cozad, R.; Wynn, G.; Ozdemir, A.C.; Conneely, K.N.; Mulle, J.G.; Dharamrup, S.; et al. Mouse model implicates GNB3 duplication in a childhood obesity syndrome. Proc. Natl. Acad. Sci. 2013, 110, 14990-14994. [CrossRef]

61. Lagman, D.; Callado-Perez, A.; Franzen, I.E.; Larhammar, D.; Abalo, X.M. Transducin duplicates in the zebrafish retina and pineal complex: Differential specialisation after the teleost tetraploidisation. PLoS ONE 2015, 10, e0121330. [CrossRef] [PubMed]

62. Wang, Q.; Levay, K.; Chanturiya, T.; Dvoriantchikova, G.; Anderson, K.L.; Bianco, S.D.; Ueta, C.B.; Molano, R.D.; Pileggi, A.; Gurevich, E.V.; et al. Targeted deletion of one or two copies of the G protein $\beta$ subunit $G \beta 5$ gene has distinct effects on body weight and behavior in mice. FASEB J. 2011, 25, 3949-3957. [CrossRef] [PubMed] 
63. Zhang, J.H.; Pandey, M.; Seigneur, E.M.; Panicker, L.M.; Koo, L.; Schwartz, O.M.; Chen, W.; Chen, C.K.; Simonds, W.F. Knockout of $\mathrm{G}$ protein $\beta 5$ impairs brain development and causes multiple neurologic abnormalities in mice. J. Neurochem. 2011, 119, 544-554. [CrossRef] [PubMed]

64. Xie, K.; Ge, S.; Collins, V.E.; Haynes, C.L.; Renner, K.J.; Meisel, R.L.; Lujan, R.; Martemyanov, K.A. Gß5-RGS complexes are gatekeepers of hyperactivity involved in control of multiple neurotransmitter systems. Psychopharmacology (Berl) 2012, 219, 823-834. [CrossRef] [PubMed]

65. Chen, C.K.; Eversole-Cire, P.; Zhang, H.; Mancino, V.; Chen, Y.J.; He, W.; Wensel, T.G.; Simon, M.I. Instability of GGL domain-containing RGS proteins in mice lacking the G protein $\beta$-subunit G $\beta 5$. Proc. Natl. Acad. Sci. USA 2003, 100, 6604-6609. [CrossRef] [PubMed]

66. Lodder, E.M.; De Nittis, P.; Koopman, C.D.; Wiszniewski, W.; Moura de Souza, C.F.; Lahrouchi, N.; Guex, N.; Napolioni, V.; Tessadori, F.; Beekman, L.; et al. GNB5 mutations cause an autosomal-recessive multisystem syndrome with sinus bradycardia and cognitive disability. Am. J. Hum. Genet. 2016, 99, 704-710. [CrossRef] [PubMed]

67. Thurmond, J.; Goodman, J.L.; Strelets, V.B.; Attrill, H.; Gramates, L.S.; Marygold, S.J.; Matthews, B.B.; Millburn, G.; Antonazzo, G.; Trovisco, V.; et al. FlyBase 2.0: The next generation. Nucleic Acids Res. 2019, 47, D759-D765. [CrossRef]

68. Robatzek, M.; Niacaris, T.; Steger, K.; Avery, L.; Thomas, J.H. Eat-11 encodes GPB-2, a G $\beta_{5}$ ortholog that interacts with $\mathrm{G}_{\mathrm{o}} \alpha$ and $\mathrm{G}_{\mathrm{q}} \alpha$ to regulate C. elegans behavior. Curr. Biol. 2001, 11, 288-293. [CrossRef]

69. Arno, G.; Holder, G.E.; Chakarova, C.; Kohl, S.; Pontikos, N.; Fiorentino, A.; Plagnol, V.; Cheetham, M.E.; Hardcastle, A.J.; Webster, A.R.; et al. Recessive retinopathy consequent on mutant G-protein $\beta$ subunit 3 (GNB3). JAMA Ophthalmol. 2016, 134, 924-927. [CrossRef]

70. Das, R.G.; Becker, D.; Jagannathan, V.; Goldstein, O.; Santana, E.; Carlin, K.; Sudharsan, R.; Leeb, T.; Nishizawa, Y.; Kondo, M.; et al. Genome-wide association study and whole-genome sequencing identify a deletion in LRIT3 associated with canine congenital stationary night blindness. Sci. Rep. 2019, 9, 14166. [CrossRef]

71. Zeitz, C.; Robson, A.G.; Audo, I. Congenital stationary night blindness: An analysis and update of genotype-phenotype correlations and pathogenic mechanisms. Prog. Retin. Eye Res. 2015, 45, 58-110. [CrossRef] [PubMed]

72. Ritchey, E.R.; Bongini, R.E.; Code, K.A.; Zelinka, C.; Petersen-Jones, S.; Fischer, A.J. The pattern of expression of guanine nucleotide-binding protein $\beta 3$ in the retina is conserved across vertebrate species. Neuroscience 2010, 169, 1376-1391. [CrossRef] [PubMed]

73. Lee, R.H.; Lieberman, B.S.; Yamane, H.K.; Bok, D.; Fung, B.K. A third form of the G protein $\beta$ subunit. 1. Immunochemical identification and localization to cone photoreceptors. J. Biol. Chem. 1992, 267, 24776-24781. [PubMed]

74. Peng, Y.W.; Robishaw, J.D.; Levine, M.A.; Yau, K.W. Retinal rods and cones have distinct G protein $\beta$ and $\gamma$ subunits. Proc. Natl. Acad. Sci. 1992, 89, 10882-10886. [CrossRef] [PubMed]

75. Nikonov, S.S.; Lyubarsky, A.; Fina, M.E.; Nikonova, E.S.; Sengupta, A.; Chinniah, C.; Ding, X.Q.; Smith, R.G.; Pugh, E.N., Jr.; Vardi, N.; et al. Cones respond to light in the absence of transducin $\beta$ subunit. J. Neurosci. 2013, 33, 5182-5194. [CrossRef] [PubMed]

76. Dhingra, A.; Ramakrishnan, H.; Neinstein, A.; Fina, M.E.; Xu, Y.; Li, J.; Chung, D.C.; Lyubarsky, A.; Vardi, N. $\mathrm{G} \beta 3$ is required for normal light $\mathrm{ON}$ responses and synaptic maintenance. J. Neurosci. 2012, 32, 11343-11355. [CrossRef] [PubMed]

77. Tummala, H.; Ali, M.; Getty, P.; Hocking, P.M.; Burt, D.W.; Inglehearn, C.F.; Lester, D.H. Mutation in the guanine nucleotide-binding protein $\beta-3$ causes retinal degeneration and embryonic mortality in chickens. Invest. Ophthalmol. Vis. Sci. 2006, 47, 4714-4718. [CrossRef]

78. Siffert, W.; Rosskopf, D.; Siffert, G.; Busch, S.; Moritz, A.; Erbel, R.; Sharma, A.M.; Ritz, E.; Wichmann, H.E.; Jakobs, K.H.; et al. Association of a human G-protein $\beta 3$ subunit variant with hypertension. Nat. Genet. 1998, 18, 45-48. [CrossRef]

79. Sousa, A.C.; Reis, R.P.D.; Pereira, A.; Borges, S.; Gouveia, S.; Spinola, A.; Freitas, A.I.; Guerra, G.; Gois, T.; Rodrigues, M.; et al. The genetic variant C825T of the $\beta 3$ subunit of $G$ protein is associated with hypertension in a Portuguese population. Rev. Port. Cardiol. 2018, 37, 499-507. [CrossRef] 
80. Rong, S.L.; Zheng, J.Z.; Wang, X.L.; Zhang, C.Y.; Su, J.; Li, B. Association of G-protein $\beta 3$ subunit C825T polymorphism with essential hypertension: Evidence from 63,729 subjects. J. Hum. Hypertens. 2017, 31, 511-514. [CrossRef]

81. Hengstenberg, C.; Schunkert, H.; Mayer, B.; Doring, A.; Lowel, H.; Hense, H.W.; Fischer, M.; Riegger, G.A.; Holmer, S.R. Association between a polymorphism in the G protein $\beta 3$ subunit gene (GNB3) with arterial hypertension but not with myocardial infarction. Cardiovasc. Res. 2001, 49, 820-827. [CrossRef]

82. Moselhy, S.S.; Alhetari, Y.A.; Iyer, A.; Huwait, E.A.; Al-Ghamdi, M.A.; Al-Ghamdi, S.; Balamash, K.S.; Basuni, A.A.; Alama, M.N.; Kumosani, T.A.; et al. Analysis of SNPs of MC4R, GNB3 and FTO gene polymorphism in obese Saudi subjects. Afr. Health Sci. 2017, 17, 1059-1069. [CrossRef] [PubMed]

83. Rizvi, S.; Raza, S.T.; Rahman, Q.; Mahdi, F. Role of GNB3, NET, KCNJ11, TCF7L2 and GRL genes single nucleotide polymorphism in the risk prediction of type 2 diabetes mellitus. 3 Biotech. 2016, 6, 255. [CrossRef] [PubMed]

84. Chen, P.S.; Chang, H.H.; Huang, C.C.; Lee, C.C.; Lee, S.Y.; Chen, S.L.; Huang, S.Y.; Yang, Y.K.; Lu, R.B. A longitudinal study of the association between the GNB3 C825T polymorphism and metabolic disturbance in bipolar II patients treated with valproate. Pharm. J. 2017, 17, 155-161. [CrossRef] [PubMed]

85. Prystupa, L.N.; Moiseyenko, I.O.; Garbuzova, V.Y.; Kmyta, V.V.; Dudchenko, I.A. Association of metabolic syndrome components with the genotypes of the C825T polymorphism in the G protein $\beta 3$-subunit gene (GNB3). Wiadomosci Lekarskie 2018, 71, 1242-1249. [PubMed]

86. Ma, J.; Wang, L.; Yang, Y.; Qiao, Z.; Fang, D.; Qiu, X.; Yang, X.; Zhu, X.; He, J.; Pan, H.; et al. GNB3 and CREB1 gene polymorphisms combined with negative life events increase susceptibility to major depression in a Chinese Han population. PLoS ONE 2017, 12, e0170994. [CrossRef] [PubMed]

87. Zill, P.; Baghai, T.C.; Zwanzger, P.; Schule, C.; Minov, C.; Riedel, M.; Neumeier, K.; Rupprecht, R.; Bondy, B. Evidence for an association between a G-protein $\beta 3$-gene variant with depression and response to antidepressant treatment. Neuroreport 2000, 11, 1893-1897. [CrossRef]

88. Nam, Y.J.; Cho, C.H.; Kim, L.; Lee, H.J. Association of G-protein $\beta 3$ subunit C825T polymorphism with seasonal variations in mood and behavior. Psychiatry Investig. 2018, 15, 200-204. [CrossRef]

89. Song, Y.Z.; You, H.Y.; Zhu, Z.H.; Wen, Z.D.; Xu, H.Y.; Chen, B.C.; Chen, Z.J.; Huang, Q.K. The C825T polymorphism of the G-protein $\beta 3$ gene as a risk factor for functional dyspepsia: A meta-analysis. Gastroenterol. Res. Pr. 2016, 2016, 5037254. [CrossRef]

90. Triantafyllou, K.; Kourikou, A.; Gazouli, M.; Karamanolis, G.P.; Dimitriadis, G.D. Functional dyspepsia susceptibility is related to CD14, GNB3, MIF, and TRPV1 gene polymorphisms in the Greek population. Neurogastroenterol. Motil. 2017, 29. [CrossRef]

91. Morrison, A.C.; Doris, P.A.; Folsom, A.R.; Nieto, F.J.; Boerwinkle, E. G-protein $\beta 3$ subunit and $\alpha$-adducin polymorphisms and risk of subclinical and clinical stroke. Stroke 2001, 32, 822-829. [CrossRef] [PubMed]

92. Zhang, L.; Zhang, H.; Sun, K.; Song, Y.; Hui, R.; Huang, X. The 825C/T polymorphism of G-protein $\beta 3$ subunit gene and risk of ischaemic stroke. J. Hum. Hypertens. 2005, 19, 709-714. [CrossRef] [PubMed]

93. Schreieck, J.; Dostal, S.; von Beckerath, N.; Wacker, A.; Flory, M.; Weyerbrock, S.; Koch, W.; Schomig, A.; Schmitt, C. C825T polymorphism of the G-protein $\beta 3$ subunit gene and atrial fibrillation: Association of the TT genotype with a reduced risk for atrial fibrillation. Am. Heart J. 2004, 148, 545-550. [CrossRef] [PubMed]

94. Zhu, W.; Li, J.; Sun, X.; Hua, Q. Association of G-protein $\beta 3$ subunit gene C825T polymorphism with cardiac and cerebrovascular events in Chinese hypertensive patients. Clin. Exp. Hypertens. 2017, 39, 80-84. [CrossRef]

95. Eba, A.; Raza, S.T.; Abbas, M.; Rizvi, S.; Rajput, M.; Mahdi, F. Association of SDF1ß (G801A) and GNB3 (C825T) polymorphisms with the incidence and severity of coronary artery disease. Br. J. Biomed. Sci. 2019, 76, 49-51. [CrossRef]

96. Nakao, R.; Tanaka, H.; Takitani, K.; Kajiura, M.; Okamoto, N.; Kanbara, Y.; Tamai, H. GNB3 C825T polymorphism is associated with postural tachycardia syndrome in children. Pediatr. Int. 2012, 54, 829-837. [CrossRef]

97. Frey, U.H.; Moebus, S.; Mohlenkamp, S.; Kalsch, H.; Bauer, M.; Lehmann, N.; Nothen, M.; Muhleisen, T.W.; Stang, A.; Erbel, R.; et al. GNB3 gene 825 TT variant predicts hard coronary events in the population-based Heinz Nixdorf Recall study. Atherosclerosis 2014, 237, 437-442. [CrossRef] 
98. Wascher, T.C.; Paulweber, B.; Malaimare, L.; Stadlmayr, A.; Iglseder, B.; Schmoelzer, I.; Renner, W. Associations of a human $\mathrm{G}$ protein $\beta 3$ subunit dimorphism with insulin resistance and carotid atherosclerosis. Stroke 2003, 34, 605-609. [CrossRef]

99. Casiglia, E.; Tikhonoff, V.; Boschetti, G.; Bascelli, A.; Saugo, M.; Guglielmi, G.; Caffi, S.; Rigoni, G.; Giordano, N.; Grasselli, C.; et al. The C825T GNB3 polymorphism, independent of blood pressure, predicts cerebrovascular risk at a population level. Am. J. Hypertens. 2012, 25, 451-457. [CrossRef]

100. D'Angelo, C.S.; Varela, M.C.; de Castro, C.I.E.; Otto, P.A.; Perez, A.B.A.; Lourenco, C.M.; Kim, C.A.; Bertola, D.R.; Kok, F.; Garcia-Alonso, L.; et al. Chromosomal microarray analysis in the genetic evaluation of 279 patients with syndromic obesity. Mol. Cytogenet. 2018, 11, 14. [CrossRef]

101. Soong, B.W.; Huang, Y.H.; Tsai, P.C.; Huang, C.C.; Pan, H.C.; Lu, Y.C.; Chien, H.J.; Liu, T.T.; Chang, M.H.; Lin, K.P.; et al. Exome sequencing identifies GNB4 mutations as a cause of dominant intermediate Charcot-Marie-Tooth disease. Am. J. Hum. Genet. 2013, 92, 422-430. [CrossRef] [PubMed]

102. Lassuthova, P.; Safka Brozkova, D.; Neupauerova, J.; Krutova, M.; Mazanec, R.; Seeman, P. Confirmation of the GNB4 gene as causal for Charcot-Marie-Tooth disease by a novel de novo mutation in a Czech patient. Neuromuscul. Disord. 2017, 27, 57-60. [CrossRef] [PubMed]

103. Miura, S.; Morikawa, T.; Fujioka, R.; Noda, K.; Kosaka, K.; Taniwaki, T.; Shibata, H. A novel missense variant (Gln220Arg) of GNB4 encoding guanine nucleotide-binding protein, subunit $\beta-4$ in a Japanese family with autosomal dominant motor and sensory neuropathy. Eur. J. Med. Genet. 2017, 60, 474-478. [CrossRef] [PubMed]

104. Wall, M.A.; Posner, B.A.; Sprang, S.R. Structural basis of activity and subunit recognition in G protein heterotrimers. Structure 1998, 6, 1169-1183. [CrossRef]

105. Gaudet, R.; Bohm, A.; Sigler, P.B. Crystal structure at 2.4 angstroms resolution of the complex of transducin $\beta \gamma$ and its regulator, phosducin. Cell 1996, 87, 577-588. [CrossRef]

106. Khan, S.M.; Min, A.; Gora, S.; Houranieh, G.M.; Campden, R.; Robitaille, M.; Trieu, P.; Petrin, D.; Jacobi, A.M.; Behlke, M.A.; et al. G $\beta_{4} \gamma_{1}$ as a modulator of M3 muscarinic receptor signalling and novel roles of $G \beta_{1}$ subunits in the modulation of cellular signalling. Cell Signal. 2015, 27, 1597-1608. [CrossRef]

107. Chandler, N.J.; Greener, I.D.; Tellez, J.O.; Inada, S.; Musa, H.; Molenaar, P.; Difrancesco, D.; Baruscotti, M.; Longhi, R.; Anderson, R.H.; et al. Molecular architecture of the human sinus node: Insights into the function of the cardiac pacemaker. Circulation 2009, 119, 1562-1575. [CrossRef]

108. Ruiz-Velasco, V.; Ikeda, S.R.; Puhl, H.L. Cloning, tissue distribution, and functional expression of the human G protein $\beta 4$-subunit. Physiol. Genom. 2002, 8, 41-50. [CrossRef]

109. Fleischmann, B.K.; Duan, Y.; Fan, Y.; Schoneberg, T.; Ehlich, A.; Lenka, N.; Viatchenko-Karpinski, S.; Pott, L.; Hescheler, J.; Fakler, B. Differential subunit composition of the G protein-activated inward-rectifier potassium channel during cardiac development. J. Clin. Invest. 2004, 114, 994-1001. [CrossRef]

110. Rosskopf, D.; Nikula, C.; Manthey, I.; Joisten, M.; Frey, U.; Kohnen, S.; Siffert, W. The human G protein $\beta 4$ subunit: Gene structure, expression, G $\gamma$ and effector interaction. FEBS Lett. 2003, 544, 27-32. [CrossRef]

111. den Hoed, M.; Eijgelsheim, M.; Esko, T.; Brundel, B.J.; Peal, D.S.; Evans, D.M.; Nolte, I.M.; Segre, A.V.; Holm, H.; Handsaker, R.E.; et al. Identification of heart rate-associated loci and their effects on cardiac conduction and rhythm disorders. Nat. Genet. 2013, 45, 621-631. [CrossRef] [PubMed]

112. Smolock, E.M.; Ilyushkina, I.A.; Ghazalpour, A.; Gerloff, J.; Murashev, A.N.; Lusis, A.J.; Korshunov, V.A. Genetic locus on mouse chromosome 7 controls elevated heart rate. Physiol. Genom. 2012, 44, 689-698. [CrossRef] [PubMed]

113. Patil, D.N.; Rangarajan, E.S.; Novick, S.J.; Pascal, B.D.; Kojetin, D.J.; Griffin, P.R.; Izard, T.; Martemyanov, K.A. Structural organization of a major neuronal G protein regulator, the RGS7-G $\beta 5$-R7BP complex. eLIFE 2018, 7, e42150. [CrossRef] [PubMed]

114. Xie, K.; Masuho, I.; Brand, C.; Dessauer, C.W.; Martemyanov, K.A. The complex of G protein regulator RGS9-2 and $G \beta_{5}$ controls sensitization and signaling kinetics of type 5 adenylyl cyclase in the striatum. Sci. Signal. 2012, 5, ra63. [CrossRef] [PubMed]

115. Witherow, D.S.; Slepak, V.Z. A novel kind of G protein heterodimer: The G $\beta 5$-RGS complex. Recept. Channels 2003, 9, 205-212. [PubMed]

116. Sanchez-Blazquez, P.; Rodriguez-Diaz, M.; Lopez-Fando, A.; Rodriguez-Munoz, M.; Garzon, J. The Gß5 subunit that associates with the R7 subfamily of RGS proteins regulates mu-opioid effects. Neuropharmacology 2003, 45, 82-95. [CrossRef] 
117. Nini, L.; Zhang, J.H.; Pandey, M.; Panicker, L.M.; Simonds, W.F. Expression of the Gß5/R7-RGS protein complex in pituitary and pancreatic islet cells. Endocrine 2012, 42, 214-217. [CrossRef]

118. Sondek, J.; Siderovski, D.P. G $\gamma$-like (GGL) domains: New frontiers in G-protein signaling and $\beta$-propeller scaffolding. Biochem. Pharm. 2001, 61, 1329-1337. [CrossRef]

119. Xie, K.; Allen, K.L.; Kourrich, S.; Colon-Saez, J.; Thomas, M.J.; Wickman, K.; Martemyanov, K.A. G $\beta 5$ recruits R7 RGS proteins to GIRK channels to regulate the timing of neuronal inhibitory signaling. Nat. Neurosci. 2010, 13, 661-663. [CrossRef]

120. Shao, Z.; Tumber, A.; Maynes, J.; Tavares, E.; Kannu, P.; Heon, E.; Vincent, A. Unique retinal signaling defect in GNB5-related disease. Doc. Ophthalmol. 2019. [CrossRef]

121. Poke, G.; King, C.; Muir, A.; de Valles-Ibanez, G.; Germano, M.; Moura de Souza, C.F.; Fung, J.; Chung, B.; Fung, C.W.; Mignot, C.; et al. The epileptology of GNB5 encephalopathy. Epilepsia 2019, 60. [CrossRef] [PubMed]

122. Malerba, N.; Towner, S.; Keating, K.; Squeo, G.M.; Wilson, W.; Merla, G. A NGS-targeted autism/ID Panel reveals compound heterozygous GNB5 variants in a novel patient. Front. Genet. 2018, 9, 626. [CrossRef] [PubMed]

123. Vernon, H.; Cohen, J.; De Nittis, P.; Fatemi, A.; McClellan, R.; Goldstein, A.; Malerba, N.; Guex, N.; Reymond, A.; Merla, G. Intellectual developmental disorder with cardiac arrhythmia syndrome in a child with compound heterozygous GNB5 variants. Clin. Genet. 2018, 93, 1254-1256. [CrossRef] [PubMed]

124. Turkdogan, D.; Usluer, S.; Akalin, F.; Agyuz, U.; Aslan, E.S. Familial early infantile epileptic encephalopathy and cardiac conduction disorder: A rare cause of SUDEP in infancy. Seizure 2017, 50, 171-172. [CrossRef]

125. Shamseldin, H.E.; Masuho, I.; Alenizi, A.; Alyamani, S.; Patil, D.N.; Ibrahim, N.; Martemyanov, K.A.; Alkuraya, F.S. GNB5 mutation causes a novel neuropsychiatric disorder featuring attention deficit hyperactivity disorder, severely impaired language development and normal cognition. Genome Biol. 2016, 17, 195. [CrossRef]

126. Veerman, C.C.; Mengarelli, I.; Koopman, C.D.; Wilders, R.; van Amersfoorth, S.C.; Bakker, D.; Wolswinkel, R.; Hababa, M.; de Boer, T.P.; Guan, K.; et al. Genetic variation in GNB5 causes bradycardia by augmenting the cholinergic response via increased acetylcholine-activated potassium current $\left(\mathrm{I}_{\mathrm{K}, \mathrm{ACh}}\right)$. Dis. Model. Mech. 2019, 12. [CrossRef]

127. Krispel, C.M.; Chen, C.K.; Simon, M.I.; Burns, M.E. Novel form of adaptation in mouse retinal rods speeds recovery of phototransduction. J. Gen. Physiol. 2003, 122, 703-712. [CrossRef]

128. Tian, M.; Zallocchi, M.; Wang, W.; Chen, C.K.; Palczewski, K.; Delimont, D.; Cosgrove, D.; Peng, Y.W. Light-induced translocation of RGS9-1 and Gß5L in mouse rod photoreceptors. PLOS ONE 2013, 8, e58832. [CrossRef]

129. Rao, A.; Dallman, R.; Henderson, S.; Chen, C.K. G $\beta 5$ is required for normal light responses and morphology of retinal ON-bipolar cells. J. Neurosci. 2007, 27, 14199-14204. [CrossRef]

130. Kulkarni, K.; Xie, X.; Marron Fernandez de Velasco, E.; Anderson, A.; Martemyanov, K.A.; Wickman, K.; Tolkacheva, E.G. Correction: The influences of the $\mathrm{M}_{2}$ R-GIRK4-RGS6 dependent parasympathetic pathway on electrophysiological properties of the mouse heart. PLOS ONE 2018, 13, e0200553. [CrossRef]

131. Posokhova, E.; Wydeven, N.; Allen, K.L.; Wickman, K.; Martemyanov, K.A. RGS6/G 35 complex accelerates $\mathrm{I}_{\mathrm{KACh}}$ gating kinetics in atrial myocytes and modulates parasympathetic regulation of heart rate. Circ. Res. 2010, 107, 1350-1354. [CrossRef] [PubMed]

132. Maity, B.; Stewart, A.; Yang, J.; Loo, L.; Sheff, D.; Shepherd, A.J.; Mohapatra, D.P.; Fisher, R.A. Regulator of $G$ protein signaling 6 (RGS6) protein ensures coordination of motor movement by modulating $G_{A B} A_{B}$ receptor signaling. J. Biol. Chem. 2012, 287, 4972-4981. [CrossRef] [PubMed]

(C) 2019 by the authors. Licensee MDPI, Basel, Switzerland. This article is an open access article distributed under the terms and conditions of the Creative Commons Attribution (CC BY) license (http://creativecommons.org/licenses/by/4.0/). 